Al-Fikra: Jurnal Ilmiah Keislaman, Vol. 7, No. 1, Januari-Juni 2008

PERNIKAHAN LINTAS AGAMA DALAM PERSPEKTIF JARINGAN ISLAM LIBERAL (JIL)

\section{Imam Hurmain}

Fakultas Ushuluddin UIN Suska Riau

\section{Abstract}

Cross-Religion Marriage in the Perspective of Liberal Islamic Network (JIL): The Liberal Islamic Network (JIL) is a community with progressive thoughts. The community whose routine agenda deals with the discussion of social and religious issues believe that there are different ideas with what most Muslim scholars commonly follow particularly in social aspects of Muslim daily lives (mu'ammalab). The liberal thoughts they campaign brought the writer to a comprehensive research on their cross-religion marriage perspective that is nationally known by among most people nowadays. This research was mainly aimed to find out why the Liberal Islamic Network allows a cross-religion marriage which has long been prohibited by both Islamic legal system and Indonesian positive common law. The findings of the research help the writer find the fact that the idea of the Liberal Islamic Network is based on several approaches, i.e. history, normative theology, philosophy and sociology. The Liberal Islamic Network makes some interpretations on well-known religious texts that are understood as the major issue which forbids the cross-religion marriage. It interprets these religious texts using non-liberal methods with some adjustments towards the socio-cultural condition and the context of people especially in Indonesia. The plural and universal values which have been the main icon of the Network were also proposed to be the basic value of permitting this kind of marriage.

Keywords: Cross-Religion Marriage, JIL, Pluralism

\section{Pendahuluan}

Imam Hurmain, Pernikahan Lintas Agama dalam Perspektif...

Gagasan-gagasan pembaruan di kalangan intelektual, khususnya dari Barat yang menggagas Liberalisasi Islam sangat berpengaruh terhadap pola pemikiran intelektual Indonesia. Gerakan Liberalisasi pemikiran Islam yang marak akhir-akhir ini, sebenarnya lebih berunsur pengaruh eksternal daripada perkembangan alami dari dalam tradisi pemikiran Islam. Pengaruh eksternal itu dengan mudah dapat ditelusuri dari trend pemikiran liberal di Barat dan dalam tradisi keagamaan Kristen.

Akhir-akhir ini pengaruh para pemikir Barat semakin pesat merasuk terutama melalui dua buku yang mengupas secara khusus keterkaitan Islam dengan Liberalisme. Buku tersebut adalah Liberal Islam: A Sourcbook, hasil suntingan Charles Kurzman, dan karya Leonard Binder berjudul Islamic Liberalis: A Critique of Development Ideologies. Fakta ini didukung oleh seorang penulis lagi dan pendukung Islam Liberal, Greg Barton, dalam bukunya Gagasan Islam Liberal di Indonesia. Kedua buku ini cukup berpengaruh terhadap gagasan liberalisasi Islam di Indonesia.

Pada dasarnya, jauh sebelum Barton menulis bukunya tentang gagasan Islam Liberal di Indonesia, gagasan ini sudah dikembangkan oleh tokoh-tokoh Liberal, seperti Nurcholish Madjid, Abdurrahman Wahid, Djohan Effendy dan Ahmad Wahib. Kemudian pada awal millenium ketiga, sejumlah aktivis dan intelektual muda Islam Indonesia memulai penyebaran gagasan Islam Liberal secara lebih terorganisir dan akhirnya mendirikan Jaringan Islam Liberal. Jaringan Islam Liberal (JIL) lahir di Jln. Utan Kayu 68 H Jakarta, bermula dari diskusi maya di mailinglist yang didirikan 8 maret 2001, diprakasai oleh sejumlah peneliti, anak-anak muda.

JIL di bawah koordinator Ulil Abshar Abdalla tidak hanya membawa pembaruan pemikiran Islam di bidang Aqidah dan politik. Mereka juga mengusung ide-ide tentang hukum keluarga seperti perlunya perkawinan antar-agama, terutama antara Muslimah dan non-Muslim, telah dilakukan melalui jaringan Radio $65 \mathrm{H}$, situs Islamlib.com, dan jaringan media Jawa Pos. Selama dua kali, dengan nara sumber yang sama, yaitu Zaitun Kamal dan Bimo Nugroho. Menurut kalangan JIL, larangan pernikahan lintas agama sudah tidak relevan lagi. Dari sini maka muncul pertanyaan mengapa JIL, 
A1-Fikra: Jurnal Ilmiah Keislaman, Vol. 7, No. 1, Januari-Juni 2008

membolehkan perkawinan lintas agama. Landasan apa yang mereka gunakan untuk membolehkannya?.

\section{Sekilas tentang Jaringan Islam Liberal}

Nama "Islam Liberal" menggambarkan prinsip-prinsip yang dianut oleh JIL, yaitu Islam yang menekankan kebebasan pribadi dan pembebasan dari struktur sosial-politik yang menindas. "Liberal" di sini bermakna dua: kebebasan dan pembebasan. Mereka percaya bahwa Islam selalu dilekati kata sifat, sebab pada kenyataannya Islam ditafsirkan secara bebeda-beda sesuai dengan kebutuhan penafsirnya. Kelompok ini memilih satu jenis tafsir, dan dengan demikian satu kata sifat terhadap Islam, yaitu "Liberal". Untuk mewujudkan Islam Liberal, kelompok diskusi tadi membentuk Jaringan Islam Liberal (JIL).

Jaringan Islam Liberal dideklarasikan pada 8 Maret 2001. Pada mulanya JIL hanya kelompok diskusi yang merespon fenomenafenomena sosial keagamaan, kemudian berkembang menjadi kelompok diskusi yang merespon (Milis) Islam Liberal (islamliberal@yahoogroups.com). Kelompok ini terus mendiskusikan berbagai hal mengenai Islam, negara dan isu-isu kemasyarakatan. Kelompok diskusi ini diikuti oleh lebih dari 200 anggota, termasuk para penulis, intelektual, dan pengamat politik seperti Taufik Adnan Amal, Rizal Mallarangeng, Denny JA, Eep Saifulloh Fatah, Hadimulyo, Ulil Abshar-Abdalla, Saiful Mujani, Hamid Basyaib, dan Ade Armando. ${ }^{1}$

Menurut hemat penulis, JIL tidak hanya terbatas pada mereka yang ikut dalam deklarasi di atas, akan tetapi semua pihak yang secara langsung atau tidak, terlibat dalam pengembangan pemikiran atau ideide yang digulirkan kelompok ini. Dengan demikian maka mencakup

1 Dalam sebuah diskusi tentang fatwa NU mengenai sesatnya JIL yang dilaksanakan di Universitas Wahid Hasyim, Sementara pada hari Sabtu tanggal 18 Desember 2004. (http:/islamlib.com/od/ondex.php?page=article\&id=784. 25/04/2005) Abdul Moqsith Ghazali, salah seorang kontributor JIL mengatakan bahwa secara kelembagaan JIL baru berdiri pada tahun 2001 sebagai bentuk reaksi atas semakin menjamurnya kelompok fundamentalis Islam di Indonesia.
Imam Hurmain, Pernikahan Lintas Agama dalam Perspektif..

intelektual, penulis dan akademis dalam dan luar negeri yang bekerja sama mengambangkan ide-ide JIL.

Kelahiran JIL dilatarbelakangi oleh kekhawatiran terhadap kelompok Islam fundamentalis yang diangap selalu memonopoli kebenaran dan memaksakan mereka dengan cara-cara yang justru tidak sejalan dengan nilai-nilai Islam. Oleh karena itu untuk menghambat atau mengimbangi ${ }^{2}$ gerakan Islam militant atau fundamentalis ini kalangan liberal mendeklarasikan sebuah jaringan. Dalam "deklarasi" pendiriannya disebutkan "kekhawatiran akan kebangkitan 'ekstrimisme' dan 'fundamentalisme' agama sempat membuat banyak orang khawatir akhir-akhir ini.

JIL juga bermaksud mengimbangi pemikiran kelompok yang bermaksud menerapkan syariat Islam secara formal di Indonesia. Pertama, memperkokoh inklusivisme dan humanisme. Kedua, membangun kehidupan keberagamaan yang berdasarkan pada penghormatan atas perbedaan, Ketiga, mendukung dan menyebarkan gagasan keagamaan (utamanya Islam) yang pluralis, terbuka dan humanis. Keempat, mencegah pandangan-pandangan keagamaan yang militan dan prokekerasan tidak menguasai publik. ${ }^{3}$

Landasan penafsiran yang dikembangkan oleh JIL adalah (1) membuka pintu ijtihad pada semua dimensi Islam (2) Mengutamakan semangat religion etik, bukan makna liberal teks. (3) Mempercayai kebenaran yang relatif, terbuka dan floral (4) Memihak pada yang minoritas dan tertindas (5) Menyakini kebebasan beragama (6) Memisahkan otoritas duniawi dan ukhrawi, otoritas keagamaan dan politik. ${ }^{4}$ Dari enam poin ini, sebenarnya tidak ada satupun yang "baru"

2 Adian Husaini dan Nuim Hidayat. Islam Liberal: Sejarah, Konsepsi, Penyimpangan dan Jawabannya. (Jakarta: Gema Insani Press, 2003), hlm. 8

http://islamlib.com/id/tentangkami.php. Lihat juga Kamaruzzaman Bustaman Ahmad. Wajah Baru Islam di Indonesia (Yogyakarta: UII Press, 2004), hlm. 89-90.

${ }^{4}$ Pada umumnya agenda kalangan Islam liberal adalah menentang teokrasi, mendorong demokrasi menjamin hak-hak perempuan dan teologi pluralisme serta dialog dengan non-Muslim; dalam wilayah cultural kebebasan berpikir dan gagasangagasan kemajuan. Adapun transformasinya yaitu melalui institusi pendidikan, 
A1-Fikra: Jurnal Ilmiah Keislaman, Vol. 7, No. 1, Januari-Juni 2008

dari pemikiran jaringan ini. Karena pada umumnya pernah dicuatkan oleh kaum intelektual, baik Muslim maupun non-Muslim dalam kazanah pemikiran keislaman pada zaman dahulu.

JIL mempunyai agenda yang tidak jauh berbeda dengan kalangan Islam liberal pada umumnya. ${ }^{5}$ Dalam sebuah tulisan berjudul "Empat Agenda Islam Yang Membebaskan"; Luthfi Assyaukani, salah seorang penggagas JIL yang juga dosen di Universitas Paramadina Mulya memperkenalkan empat agenda Islam Liberal. Pertama, Agenda politik. Menurutnya urusan Negara adalah murni urusan dunia, sistem kerajaan dan parlementer (demokrasi) sama saja. Kedua, Mengangkat kehidupan antar agama. Menurutnya perlu pencarian teologi pluralisme mengingat semakin majemuknya kehidupan bermasyarakat di negeri-negeri Islam. Ketiga, Emansipasi wanita. Agenda ini mengajak kaum Muslim untuk memikirkan kembali beberapa doktrin agama yang cenderung merugikan dan mendiskreditkan kaum perempuan. Hal ini karena doktrin-doktrin tersebut dari manapun sumbernya bertentangan dengan semangat dasar Islam yang mengakui persamaan dan menghormati hak-hak semua jenis kelamin (lihat misalnya Q.S. 33:35, Q.S. 49: 13, Q.S. 4: 1). Keempat, Kebebasan berpendapat (secara mutlak). Agenda ini menjadi penting dalam kehidupan kaum Muslim modern, khususnya ketika persoalan ini berkaitan erat dengan masalah hak-hak asasi manusia (HAM). Islam sudah pasti sangat menghormati hak-hak asasi manusia, dan dengan demikian, juga menghormati kebebasan berpendapat. ${ }^{6}$

Sedangkan misi JIL secara garis besar ada tiga misi utama. Pertama, mengembangkan penafsiran Islam yang liberal yang sesuai dengan prinsip yang mereka anut, serta menyebarkannya kepada seluas mungkin khalayak. Kedua, mengusahakan terbukanya ruang dialog yang bebas dari konservatisme. Mereka yakin, terbukanya ruang dialog akan memekarkan pemikiran dan gerakan Islam yang sehat. Ketiga,

penerbitan dan jaringan intelektual liberal. Yudhie Haryono R., Post Islam Liberal. (Bekasi: Airlangga Pribadi, 2002), hlm. 256-288.

5 Assyaukanie: http://islamlib.com/id/: 29/04/2001, diakses pada Kamis, 7 Juli 2005 lihat juga Husaini dan Hidayat, 2003, hlm. 3.

${ }^{6}$ Kamaruzzaman Bustamam Ahmad. Wajah Baru Islam, (Jakarta: t.p., t.th), hlm. 95.
Imam Hurmain, Pernikahan Lintas Agama dalam Perspektif...

mengupayakan terciptanya struktur sosial dan poitik yang adil dan manusiawi. Di tempat lain, Ulil menyebutkan ada tiga kaidah yang hendak dilakukan oleh JIL yaitu: Pertama, membuka ruang diskusi, meningkatkan daya kritis masyarakat dan memberikan alternatif pandangan yang berbeda. Kedua, ingin merangsang penerbitan buku dan riset-riset. Ketiga, dalam jangka panjang ingin membangun semacam lembaga pendidikan yang sesuai dengan visi JIL mengenai Islam. ${ }^{7}$

JIL mensosialisasikan dan menyebarkan pemikiran mereka. JIL mempuyai jaringan di seluruh nusantara dengan media koran (radar) Jawa Pos setiap minggu, Talk Show radio $48 \mathrm{H}$ yang disiarkan di seluruh jaringan Islam Liberal, Milist ISLIB, dan diskusi-diskusi rutin di TUK-ISAI Jakarta yang senantiasa membahas tema-tema penting dan berbobot oleh intelektual muda JIL atau intelektual manca negara yang kebetulan datang ke Indonesia. Selain itu JIL juga menerbitkan buku-buku yang memuat pikiran-pikiran Negara dari kelompok ini. Wajah Islam Liberal di Indonesia, 2002 (Asyaukanie, penyunting) adalah buku yang sangat jelas bertujuan mensosialisasikan pikiran-pikiran JIL di Indonesia, di samping buku kekerasan: Agama tanpa Agama, 2002, (Thomas Santoso, ed) yang diterbitkan oleh pustaka Utan Kayu. ${ }^{8}$

\section{Pernikahan Lintas Agama dalam Realitas Masyarakat Indonesia}

Pernikahan merupakan sarana untuk melahirkan generasi umat manusia yang mempunyai tugas kekhalifahan untuk memakmurkan bumi. ' Selain itu, pernikahan juga bertujuan untuk mewujudkan rumah tangga yang rukun, penuh cinta dan kasih sayang (sakinah, mawaddah wa al-rabmab). ${ }^{10}$ Kehidupan seperti ini merupakan kebutuhan

7 Zuli Qodir, Islam Liberal: Paradigma Baru Wacana dan Aksi Islam Indonesia (Yogyakarta: Pustaka Pelajar, 2003), hlm. 79

${ }^{8}$ Lihat surat al-Baqarah ayat 30; al-Naml: 62; al-A'raf: 29 dan surat Shad: 26.

9 Q.S al-Nahl ayat 72 dan Q.S al-Rum ayat 21.

10 Pada prinsipnya pandangan ulama mengenai pernikahan lintas agama ini terbagi menjadi tiga bagian; Pertama, melarang secara mutlak pernikahan antara muslim dengan non-muslim baik yang dikategorikan musyrik maupun abl al-kitab. Larangan itu juga berlaku bagi perempuan maupun laki-laki. Kedua, membolehkan 
Al-Fikra: Jurnal Ilmiah Keislaman, Vol. 7, No. 1, Januari-Juni 2008

yang telah menjadi fitrah atau naluri setiap manusia. Oleh karena itu, Islam memberikan perhatian yang cukup besar terhadap masalah perkawinan ini, termasuk pernikahan antar umat yang berbeda agama atau pernikahan lintas agama.

Pernikahan lintas agama yang dimaksud adalah pernikahan yang dilakukan antara seseorang yang beragama Islam (Muslim atau Muslimah) dengan orang non-Muslim, baik yang dikategorikan sebagai orang musyrik maupun ahli kitab. Masalah pernikahan lintas agama ini selalu menjadi bahan perdebatan di kalangan ulama, ${ }^{11}$ hal ini karena perbedaan perspektif dalam memahami ayat-ayat atau teks-teks agama yang melarang pernikahan orang Muslim dengan orang musyrik.

Meskipun pernikahan lintas agama ini tidak diperbolehkan oleh Undang-Undang, namun fenomena semacam ini terus berkembang ${ }^{12}$. Kita bisa melihat baik dari media masa maupun media elektronik, banyak sekali selebritis yang melakukan pernikahan dengan pasangan yang tidak seagama. Sebagai contoh, Jamal Mirdad seorang Muslim, menikah dengan Lidia Kandaw yang beragama Kristen; Nurul Arifin

secara bersyarat. Sejumlah ulama membolehkan pernikahan antara laki-laki Muslim dengan perempuan non-Muslim dari kelompok abl al-kitab. Tetapi perempuan Muslim tidak boleh menikah dengan laki-laki non-Muslim walaupun tergolong $a b$ al-kitab. Ketiga, membolehkan pernikahan antara Muslim dengan non-Muslim yang berlaku untuk laki-laki dan perempuan Muslim. Salahuddin Wahid, "Perkawinan Agama dan Negara", Republika, Jumat, 1 April 2005, hlm. 2; Namun pendapat ini ditanggapi oleh Adian Husaini dalam artikelnya berjudul "Pernikahan Lintas Agama" yang dimuat di harian Republika Jumat, 15 April 2005. Dalam tulisan in menyatakan bahwa pernyataan Wahid diatas tidak tepat. Menurut Adian tidak ada ulama yang membolehkan wanita Muslimah menikah dengan laki-laki non-Muslim. Sayyid Sabiq, dalam Fiqib Sunnah, menegaskan bahwa semua ulama bersepakat tentang haramnya pernikahan antara wanita Muslimah dengan laki-laki nonMuslim. Sepanjang sejarah Islam tidak ada perbedaan mengenai hal itu.

${ }^{11}$ Nurnyamin Aini dalam tesisnya di Flinders University, Australia. Dalam penelitian itu, Nurnyamin Aini, menjadikan masyarakat Daerah Istimewa Yogyakarta sebagai sampel penelitian. Dari data penelitian ini ditemukan bahwa jumlah pernikahan lintas agama di DIY mengalami fluktuasi. Pada tahun 1980 paling tidak ada 15 kasus pernikahan beda agama dari 1000 kasus pernikahan yang tercatat. Pada tahun 1990 naik menjadi 18 kasus dan pada tahun 2000 menurun menjadi 12 kasus.

12 Ahmad Nurcholis, Memoar Cintaku, (Yogyakarta: LKiS, 2004), hlm. 3.
Imam Hurmain, Pernikahan Lintas Agama dalam Perspektif..

(Muslimah), dengan Mayong (Katholik); Ina Indayatai (Muslimah), menikah dengan Jeremi Thomas yang beragama Kristen; Frans Lingua (Kristen), menikah dengan Amara (Islam); Yuni Shara (Muslimah) menikah dengan Hendry Siahaan (Kristen); Ari Sigit (Muslim) menikah dengan Rica Callebut (Kristen); Ari Sihasale (Kristen) menikahi Nia Zulkarnain yang beragama Islam. Pernikahan Dedy Corbuzer yang beragama Katholik dengan Kalina yang beragama Islam. Selain itu, tentunya masih sangat banyak peristiwa semacam in yang tidak terdeteksi oleh media. Umumnya, selain undang-undang yang berlaku di Indonesia, ajaran agama ternyata sedikit banyaknya juga menjadi "penghalang" pernikahan. Sehingga di antara mereka sebagian besar berinisiatif melakukan perkawinan di luar negeri, atau cara lain yaitu mengadakan perkawinan menurut agama kedua belah pihak. Selain itu banyak juga pasangan yang melaksanakan akad perkawinan lintas agama di Kantor Catatan Sipil. Kantor Catatan Sipil mau melaksanakan perkawinan ini berdasarkan kebijakan yang mereka ambil sendiri dengan dasar pemikiran "dari pada mereka hidup bersama di luar perkawinan, lebih baik Catatan Sipil meresmikannya saja". Namun pihak-pihak yang akan melaksanakan akad harus membawa surat dispensasi dari Pegawai Pencatat Nikah atau dari Departemen Agama. ${ }^{13}$

Cara-cara di atas dilakukan karena Undang-Undang negara kita tidak memperbolehkan pernikahan lintas agama. Undang-undang No. 1 tahun 1974 Pasal 2 ayat (1) yang menyatakan bahwa "perkawinan adalah sah apabila dilakukan menurut hukum masing-masing agama dan kepercayaannya itu" dan bab VI, mengenai larangan kawin, Pasal 40 ayat (c). Pasal itu berbunyi bahwa "seorang laki-laki Muslim tidak diperbolehkan mengawini perempuan yang tidak beragama Islam”, serta fatwa Majelis Ulama Indonesia tahun 1980 yang menyatakan bahwa perkawinan lintas agama tidak absah. Pada dasarnya peraturanperaturan ini dan tidak dapat mencegah atau menjawab realitas yang berkembang di masyarakat, apalagi dengan kenyataan pluralitas dan kemajemukan masyarakat Indonesia, fenomena pernikahan lintas

13 Rusli dan R. Tama, Perkawinan Antar Agama dan Masalahnya, (Bandung: Pionir Jaya, 1986). Hlm. 37-38. 
A1-Fikra: Jurnal Ilmiah Keislaman, Vol. 7, No. 1, Januari-Juni 2008 agama semakin banyak ditemukan. Melihat realitas semacam ini Jaringan Islam Liberal yang berpandangan progresif-liberal menyatakan bahwa larangan pernikahan antara agama sudah tidak relevan lagi.

\section{Pernikahan Lintas Agama dalam Perspektif Jaringan Islam Liberal (JIL)}

Perkawinan lintas agama bukan hanya merupakan problem yang terjadi antar pemeluk agama yang berbeda, akan tetapi dalam satu agama pun merupakan problem yang dari dulu belum terpecahkan. Dalam Islam sendiri terjadi banyak perbedaan pendapat tentang hukum pernikahan lintas agama ini. Dalam hal ini JIL yang berpandangan dengan dasar realativisme kebenaran agama dan kemaslahatan, tidak mempermasalahkan perkawinan antara seorang Muslim dengan non-Muslim, baik laki-laki maupun perempuan.

Ulil Abshar Abdalla, koordinator JIL mengatakan bahwa larangan pernikahan lintas agama sudah tidak relevan lagi. Menurutnya, al-Qur'an juga tidak pernah secara tegas melarang hal itu, karena al-Qur'an menganut pandangan universal tentang martabat manusia yang sederajat, tanpa melihat perbedaan agama. Segala produk hukum Islam klasik yang membedakan kedudukan orang Islam dan non-Islam harus diamandemen berdasarkan prinsip kesederajatan universal dalam tataran kemanusiaan. ${ }^{14}$

Berpikir secara tekstual saja pernikahan beda agama antara lakilaki Muslim dengan wanita ahli kitab, begitu juga antara wanita Muslim dengan laki-laki non-Muslim (ahli kitab) menurut Abdu Moqsith Ghazali, salah satu "petinggi" JIL diperbolehkan. Moqsith mengqiyaskannya dengan hadis tentang kewajiban menuntut ilmu. Dalam hadis tersebut tidak ditemukan kata, "Muslimatin" namun pada kenyataannya wanita juga diwajibkan menuntut ilmu. Ini dapat dilihat

14 Ulil Abshar Abdalla, Menyegarkan Kembali Pemahaman Islam, Kompas, Senin, 18 November 2002
Imam Hurmain, Pernikahan Lintas Agama dalam Perspektif..

dalam kitab Jurmiyah bab al-iktifa'.15 Sebagai contoh, dalam kitab ini disebutkan hadis di atas (thalabul 'ilmi faridhatun 'ala kulli Muslimin). Di dalam al-Qur'an tidak dicantumkan hukum pernikahan wanita Muslimah dengan laki-laki non-Muslim tidak dicantum sebaliknya, min bab al-iktifa'. Karena itu berlaku hukum sebaliknya (Mafbumm al mukhalafah). Selain itu dalam teks-teks agama tidak ditemukan dalil yang melarang pernikahan perempuan Muslimah dengan laki-laki nonMuslim. Menurut Abdul Moqsith Ghazali, salah satu promotor JIL, tidak ada dalil yang melarang itu adalah "dalil diperbolehkannya pernikahan di antara mereka". Ia menyebutkan salah satu kaidah ushuliyah, 'adam al-dalil buwa al-dalil. Karena tidak ada dalil al-Qur'an yang melarang, maka berarti sudah menajadi dalil diperbolehkannya, sehingga pernikahan perempuan Muslimah dengan laki-laki nonMuslim diperbolehkan. ${ }^{16}$ Jadi pernikahan orang Islam, baik antar lakilaki maupun perempuan dengan agama apapun menurut JIL boleh dilakukan. Ada beberapa pokok pikiran yang dijadikan landasan untuk membolehkan pernikahan lintas agama ini.

\section{a. Landasan Historis}

Secara teoritis, pernikahan antara orang Muslim dengan ahli kitab memang pernah terjadi. Pada zaman sahabat misalnya, Utsman bin Affan menikah dengan Bailah binti Qaraqashah al-Kalbiyah beragama Nasrani, Thalhah bin Ubaidillah dengan perempuan Yahudi di Damaskus, Hudzaifah menikah dengan wanita Yahudi di Madinah. Demikian halnya dengan para sahabat lainnya seperti Ibn Abbas, Jabir, Ka'bah bin Malik, Al-Mughirah bin Syu'bah pernah menikah dengan wanita ahli kitab. Bahkan Nabi sendiri menikah dengan Maria Koptik yang semula beragama non-Islam. ${ }^{17}$ Selain itu, pemimpin Plestina,

15 Entah Moqsith atau penulis yang salah melihat setelah para medis mencoba mengecek langsung bab al-Iktifa', ini dalam kitab Jurmiyah, ternyata di sana tidak ada bab yang dimaksud.

16 Abdul Moqisth Ghazali, dalam sebuah diskusi tentang fatwa NU mengenai sesamanya JIL yang dilaksanakan di Universitas Wahid Hasyim, Semarang pada hari Sabtu tanggal $18 \quad$ Desember 2004 (http://islamlib.com/id/index..php?page=articlesaid=784. 25/04/2005).

${ }^{17}$ Lihat Zainun Kamal dalam Ahmad Nurcholis, Memoar Cintaku, hlm. 149 
Al-Fikra: Jurnal Ilmiah Keislaman, Vol. 7, No. 1, Januari-Juni 2008

Yasser Arafat menikah dengan Suha yang beragama Yahudi, dan pernikahan itu tidak menjadi masalah di Negara Palestina.

Landasan historis di atas sebenarnya kurang relevan. Sebelum prnikahan Rasulullah dengan Shafiyyah binti Hayy bin Akhtab dan Mariah Qibtiyah, keduanya sudah terlebih dahulu memeluk Islam. ${ }^{18}$ Sementara tentang pernikahan Hudzaifah dan Thalhah, ini dilarang oleh Umar bin Khatab ${ }^{19}$ dengan alasan khawatir akan diikuti oleh kaum Muslimin yang lain. Umar juga memerintahkan keduanya untuk menceraikan isteri mereka. ${ }^{20}$ Menurut Abdul Muta'al Al-Jabri, pernikahan para sahabat dengan wanita-wanita ahli kitab ini tidak dapat dijadikan landasan untuk membolehkan pernikahan pria Muslim dengan wanita ahli kitab atau non-Muslim, karena pernikahan tersebut ditentang oleh sebagian sahabat yang lain.

Ulama sepakat bahwa ucapan sahabat (qaul shahaiy) dan perilaku sahabat atau madzhab shahabiy yang bersumber dari Rasulullah SAW atau yang sudah menjadi kesepakatan di kalangan sahabat merupakan dalil syari'i. Namun ulama berbeda pendapat tentang ucapan sahabat (qaul shahabiy) atau perilaku sahabat atau madzhab shababiy yang tidak bersumber dari Rasulullah SAW atau hasil ijtihad mereka sendiri dan tidak ada kesepakatan di antara sahabat. Ada dua pendapat ulama, yaitu pertama, ulama yang mengatakan bahwa ucapan atau perbuatan sahabat tersebut merupakan dalil syar'i, karena jarang sekali terjadi kesalahan ketika sahabat melakukan ijtihad. Hal ini karena mereka mengetahui langsung proses turunnya Al-Quran, asbab al-nu₹ul serta paham akan makna dan kandungannya. Kedua, pendapat yang

18 Abdul Muta' Muhammad al-Jabry, Pernikahan Campuran Menurut Pandangan Islam, (Surabaya: Risalah Gusti, 1992), hlm. 150-154.

19 Larangan Umar ini, oleh Zainun Kamal, salah seorang kontributor JIL, dinilai sebagai larangan secara politis, karena melihat tinjauan strategis itu. Larangan ini bisa dibaca sebagai larangan kekuasaan dan bukan larangan agama, karena ada persoalan sosial pada masa itu. Waktu itu Islam dalam penyebaran ajarannya mengalami banyak sekali tantangan dari luar. Banyak Sahabat yang meninggal dalam medan perang yang menyebabkan meningkatnya jumlah janda dari kalangan kaum muslimin. (Zainun Kamal, Nikah Beda Agama, www.islamlib.com. 30/06/02)

${ }_{20}$ Al-Thabariy. Tafsir al-Thabariy. (Beirut: Dar al-Kutub al-'Tlmiyah, 1999), hlm.
Imam Hurmain, Pernikahan Lintas Agama dalam Perspektif...

mengatakan ${ }^{21}$ bahwa ucapan atau perbuatan sahabat yang tidak bersumber dari Al-Quran atau dari Rasulullah atau tidak ada kesepakatan di antara mereka, tidak dapat dijadikan dalil syrar'i, karena sahabat merupakan manusia biasa yang juga dapat melakukan kesalahan. ${ }^{22}$

\section{b. Landasan Teologis Normatif}

Penulis memahami Jaringan Islam Liberal sebagai liberal interpreted syariah. $^{23}$ Mereka berasumsi bahwa Islam membuka kemungkinan liberal pada masalah-masalah yang dimungkinkan munculnya penafsiran (interpretable). JIL masih menggunakan teks-teks agama sebagai dalil, namun mengedepankan epistemologi yang menekankan perlunya keragaman di dalam menafsirkan teks-teks yang dianggap melarang pernikahan beda agama. Ayat-ayat yang berkaitan dengan hal ini antara lain QS. al-Baqarah: 221; QS. alMumtahanah: 10 dan QS al-Maidah: 5.

21 Di antara yang menyatakan pendapat ini adalah Imam Syafi'iy. Syafi'iy mengatakan bahwa tidak boleh menetapkan hukum atau berfatwa kecuali datang dari sumber yang jelas, yaitu Al-Quran dan Hadis dan pendapat ulama yang sudah disepakati atau yang telah diqiyaskan kepada tiga hal itu. Abdul Wahab Khalaf, $\mathrm{Tlm}$ Ushul Al-Figh, (Kairo: Maktabah al-Da'wah Al-Islamiyah, 1965), hlm. 94-96. Menguatkan apa yang dikatakan oleh Abdul Wahab Khalaf, Imam Syafi'iy dalam Al-Risalah secara tegas mengatakan: "tidak boleh bagi seseorang, selamanya, untuke mengatakan halal atau haram, kecuali berdasarkan ilmu, dan dasar ilmu adalab khabar dalam kitab Allah, sunnah Nabi, ijma', atau qiyas”. Lihat Syafi'iy, Al-Risalah, Tahqiq: Ahmad Syakir, (Kairo: t.p., t.th), hlm. 39

22 Abdul Wahab Khalaf, Tlm Ushul Al-Fiqh; Abdul Karim Zidan, Al-Wajiq fi Ushul al-Figh, (Beirut: Muassasah al-Risalah, 1990), hlm. 260-262.

${ }_{23}$ Dua bentuk Islam liberal lainnya yaitu, syariah liberal, yaitu Islam liberal yang berpaham bahwa syari'ah itu bersifat liberal pada dirinya sendiri jika dipaham secara tepat. Dan silent syari'ah, model pembacaan ini berasumsi bahwa Islam tidak banyak berbicara mengenai isu-isu kontemporer. Islam liberal dimungkinkan terjadi pada masalah-masalah tertentu yang tidak ada presedennya dalam Islam baik secara normatif maupun historis. Karena Islam tidak banyak berbicara mengenai isu-isu kontemporer, maka diperlukan kreatifitas, terutama yang menyangkut bidang muamalah. Charles Kurzman, Wacana Islam Liberal: Pemikiran Islam Kontemporer tentang Isu-isu Global (Jakarta: Paramadina, 2003),hlm. xxxiii-xxxviii. 
Al-Fikra: Jurnal Ilmiah Keislaman, Vol. 7, No. 1, Januari-Juni 2008

Berangkat dari ayat-ayat di atas, ada tiga hal yang harus clear tentang pernikahan beda agama. Pertama, adalah tentang konsep ahli kitab. Menurut Zainun Kamal, kalau merujuk kitab-kitab tafsir, sebenarnya cakupan ahli kitab tidak terbatas hanya Yahudi dan Nasrani. Kedua, golongan ini popular disebut sebagai ahli kitab karena kedua agama ini memiliki penganut agama yang cukup banyak. Padahal, lanjutnya bila seorang sudah percaya kepada salah satu nabi maka bisa dikategorikan ahli kitab. Secara implisit Kamal mengatakan bahwa penganut agama-agaa yang diakui di Indonesia adalah ahli kitab. Ia memulai pandangannya secara makro, Al-Baghdadiy dalam bukunya al-Farq baina al-Firaq mengatakan bahwa agama Majusi atau Zoroaster yang ada di sekitar Arab juga bisa disebut ahli kitab. Hal in karena Zoroaster dianggap sebagai nabi. Bahkan Ibn Rusyd menyebut Aristoteles juga sebagai seorang nabi.

Kalau dalam konteks Indonesia ${ }^{24}$, agama Budha, Hindu, atau agama Konhucu dan Shinto, menurut Muhammad Abduh dalam kitab Tafsir al-Manar, juga disebut sebagai ahli kitab, karena ada kitab suci yang dibawa oleh seorang nabi. Nabi di sini diartikan sebagai pembawa pesan moral. Itu dikaitkan dengan ajaran al-Qur'an bahwa "Allah mengutus kepada setiap umat seorang rasul" jadi setiap umat mempunyai nabi. Dalam hal ini agama Budha bisa dikatakan bahwa Sidharta Gautama adalah seorang nabi yang membawa kitab suci. Jadi pengertian dan cakupan ahli kitab semakin meluas seiring dengan perkembangan zaman.

Atas dasar tersebut, menurut Kamal tidak ada larangan menikah dengan kaum agama lain, dalam konteks Indonesia yaitu agama Hindu, Budha, Kristen dan Protestan, dengan alasan karena mereka juga mempunyai kitab suci yang berisi pesan moral dan menjadi

${ }^{24} \mathrm{JIL}$ memegang konsep penafsiran non-literal, yaitu suatu pernafsiran yang tidak melihat lafazh-lafazh yang tertulis dalam teks, namun penafsiran yang melihat konteks sosio cultural di mana teks tersebut akan diberlakukan. Ini merupakan salah satu gagasan Ulil Abshar Abdalla, koordinator JIL yang dituangkan dalam artikel "Menyegarkan Kembali Pemabaman Islam". Dalam tulisan ini Ulil mengatakan bahwa umat Islam memerlukan penafsiran tentang Islam yang non-literal, substansial, kontekstual dan sesuai dengan denyut nadi peradaban manusia yang sedang dan terus berubah.
Imam Hurmain, Pernikahan Lintas Agama dalam Perspektif...

pegangan hidup. Adapun tentang penyimpangan atau amandemen terhadap kitab-kitab tersebut tidak menghapus status ahli kitab mereka. Kontributor JIL ini beralasan bahwa orang Yahudi dan Nasrani sudah melakukan penyimpangan terhadap kitab mereka semenjak abad ke empat masehi. Kitab suci mereka sudah mengalami perubahan sejak sebelum Islam muncul pada abad ke tujuh masehi. Pada waktu awal turunnya al-Qur'an, telah dikatakan bahwa orang Nasrani percaya kepada trinitas. Namun, walaupun demikian, alQur'an tetap meminta umat Islam untuk percaya kepada ahli kitab.

Imam Syafi'i berpendapat bahwa ahli kitab hanya terbatas pada orang-orang Yahudi dan Nasrani dari Bani Israil saja. Sedangkan dari bangsa-bangsa lain yang menganut agama Yahudi dan Nasrani tidak termamsuk ahli kitab. Alasannya, karena nabi Musa dan Isa hanya diutus khusus kepada Bani Israil saja, bukan kepada bangsa-bangsa lainnya. Sementara itu Imam Abu Hanifah dan mayoritas pakar hukum lainnya menyatakan bahwa siapa saja yang mempercayai salah seorang nabi, atau kitab yang diturunkan Allah, maka ia termasuk ahli kitab. Sehingga ahli kitab tidak hanya terbatas pada kelompok penganut agama Yahudi atau Nasrani. Bila ada yang hanya percaya kepada Shubuf nabi Ibrahim as. atau kitab Zabur saja, maka iapun termasuk ahli kitab. Bahkan di antara ulama salaf ada yang berpendapat bahwa setiap umat yang memiliki kitab yang dapat diduga sebagai kitab samawi, maka mereka juga adalah ahli kitab, seperti halnya orang-orang Majusi.

Abdullah bin Abbas berpendapat bahwa ahli kitab adalah Yahudi dan Nasrani, dan kebolehan kawin dengan perempuan-perempuan mereka hanyalah bagi mereka yang berada di bawah perlindungan pemerintahan Islam (Darul Islam) dan bukan yang tinggal di luar pemerintahan Islam dan dalam permusuhan, sahabat nabi, Abdullah bin Umar berpendapat lain, beliau secara tegas melarang perkawinan seorang pria Muslim dengan wanita ahli kitab dengan dalil bahwa mereka adalah orang-orang musyrik. Ia mengatakan "saya tidak mengetahui kemusyrikan yang lebih besar dari keyakinan orang yang 
Al-Fikra: Jurnal Ilmiah Keislaman, Vol. 7, No. 1, Januari-Juni 2008

berkata bahwa Tuhannya adalah Isa atau salah satu seorang dari hamba-hamba Allah. ${ }^{25}$

Kedua, tentang konsep musyrik. ${ }^{26}$ Menurut Zainun Kamal, tidak setiap perbuatan syirik menjadikan secara langsung pelakunya disebut musyrik. Karena pada kenyataannya Yahudi dan Nasrani telah melakukan perbuatan syirik, namun Allah tidak menyebut dan memanggil mereka sebagai musyrik, namun tetap dipanggil dengan ahl al-kitab. Hal ini dapat dilihat dalam surat An-Nisa' ayat 171, AlMaidah: 5 dan Ali Imran: 64.

Kita juga dapat memahami bahwa orang-orang Islam pun bisa melakukan perbuatan syirik, dan memang kenyataannya ada, namun mereka tidak dapat disebut sebagai kaum musyrik. Sebab sebagai konsekuensi logisnya, jika salah seorang suami-istri dari keluarga Muslim sudah disebut musyrik, maka perkawinan mereka batal (fasakh) dengan sendirinya dan mereka wajib cerai, tapi kenyataan ini tidak pernah diterima. Betapa banyak terdapat dalam kenyataan hidup ini pada orang-orang beragama, termasuk orang-orang Muslim, melakukan perbuatan syirik dalam kehidupan sehari-harinya, ${ }^{27}$ seperti orang yang mempertaruhkan hawa nafsunya. ${ }^{28}$

Ada perbedaan pemahaman kata al-Musyrikat ${ }^{29}$ dalam surat $\mathrm{Al}$ Baqarah ayat 221 antara kalangan JIL dan jumhur ulama. Dari sini muncul juga perbedaan konsep musyrik. Zainul Kamal, "kontributor" JIL mengatakan bahwa orang musyrik adalah orang yang bukan hanya mempersekutukan Allah, tetapi juga tidak mempercayai salah satu dari

25 Muhammad Qurais Shihab, Wawasan Al-Quran, (Bandung: Mizan, 2000), hlm. 369

26 Al-Quran membedakan antara kafir dan musyrik. Hal ini dapat dilihat dalam Surat Al-Maidah avat 17 dan 73 serta surat Al-Taubah ayat 30.

${ }^{27}$ Lihat surat An-Nisa' ayat 36

${ }^{28}$ Surat Al-Jatsiyah ayat 23

29 Menurut Muhammad Abduh yang dinukilkan oleh Rasyid Ridha bahwa perempuan yang haram dikawini (al-Musyrikat) oleh laki-laki Muslim dalam surat alBaqarah ayat 221 adalah perempuan musyrik Arab. (Abdullah dan Ridha, VI, tt: 193). Sedangkan menurut Mujtahid, sebagaimana dikutip dalam kitab al-Thabari, kata al-Musyrikat mencakup kaum Musyrikat secara umum, baik di Mekkah maupun di seluruh dunia, kecuali abl al kitab, al-Thabary, Tafsir, hlm. 386-392
Imam Hurmain, Pernikahan Lintas Agama dalam Perspektif...

kitab-kitab samawi, baik yang telah terdapat penyimpangan ataupun yang masih asli di samping tidak seorang nabi pun yang mereka percayai. 30

Muhammad Ali al-Shabuni dalam kitab Rawai' al-Bayan Tafsir Ayat al-Abkam min Al-Quran mengatakan, bahwa yang dimaksud dengan kata al-musyrikat dalam ayat ini adalah wanita-wanita penyembah berhala dan mereka tidak memeluk agama Samawi. ${ }^{31}$ Wahbah Zuhailiy menyatakan bahwa yang dimaksud al-musyrikat dalam ayat tersebut adalah orang yang tidak beragama dan tidak mempunyai kitab Samawi. ${ }^{32}$

Ketiga, tentang konsep kafir. Kata kafir (kufr) yang berulang sebanyak 525 kali dalam al-Qur'an, semuanya dirujukkan kepada arti "menutupi", yaitu menutup-nutupi nikmat dan kebenaran dalam arti Tuhan (sebagai sumber kebenaran) maupun kebenaran dalam arti ajaran-ajaran yang disampaikan melalui Rasul-rasul-Nya. (Harifuddin Cawidu dalam Zainun Kamal).

Seperti keimanan yang dimiliki oleh setiap orang tidak sama tingkatannya antara yang satu dengan lainnya, demikian juga kekafiran. Karena itu ada beberapa jenis kekafiran yang disebutkan Al-Quran, di antaranya:

1. Kafir (kufr) inkar, yakni kekafiran dalam arti pengingkaran terhadap eksistensi Tuhan, rasul-rasul-Nya dan seluruh ajaran yang mereka bawa.

${ }^{30}$ Kamal juga mengutip defenisi lain dari buku Al Islam fi Muwajahah al Tahaddiyat al Mu'asharah, karya Abu al A'la Al Maududi, tentang musyrik dan ahli kitab: “....dikatakan musyrik bukan hanya mempersekutukan Allah, tapi juga tidak mempercayai salah satu dari kitab Samawi, baik yang telah terdapat penyimpangan ataupun yang masih asli; di samping tidak seorang nabi pun yang mereka percayai. Adapun ahli kitab adalah orang yang mempercayai salah seorang nabi dari nabinabi dan salah satu kitab dari kitab-kitab Samawi, baik sudah terjadi penyimpangan pada mereka dalam bidang aqidah atau amalan.

${ }^{31}$ Muhammad Ali Al-Shabuni, Rawai' al-Bayan Tafsir ayat al-Ahkam min AlQuran. (Beirut: Dar al-Kutub al-Islamiyah, 2001), hlm.

${ }^{32}$ Wahbah Zuhailiy, Tafsir Al-Wasith, (Beirut: Dar al-Fikr al-Ma'ashir, 2000), hlm. 118. 
Al-Fikra: Jurnal Ilmiah Keislaman, Vol. 7, No. 1, Januari-Juni 2008

2. Kafir (kufr) juhud, yakni kekafiran dalam arti pengingkaran terhadap ajaran-ajaran Tuhan dalam keadaan tahu bahwa apa yang diingkari itu adalah benar.

3. Kafir munafik (kufr nifaq), yaitu kekafiran yang mengakui Tuhan, Rasul dan ajarannya dengan lidah tetapi mengingkarinya dengan hati, menampakkan iman dan menyembunyikan kekafiran.

4. Kafir (kufr) syirik, berarti mempersekutukan Tuhan dengan menjadikan sesuatu, selain dariNya, sebagai sembahan, obyek pemujaan, dan atau tempat menggantungkan harapan. Syirik digolongkan sebagai kekafiran sebab perbuatan itu mengingkari kekuasan Tuhan, juga mengingkari Nabi-nabi dan wahyuNya.

5. Kafir (kufr) nikmat, yakni tidak mensyukuri nikmat Tuhan dan menggunakan nikmat itu pada hal-hal yang tidak diridloiNya.

6. Kafir murtad, kembali menjadi kafir sesudah beriman atau keluar dari Islam.

7. Kafir Ahli Kitab, yakni non-Muslim yang percaya kepada nabi dan kitab suci yang diwahyukan Tuhan melalui nabi kepada mereka. ${ }^{33}$

Dari pembagian kafir dalam al-Qur'an yang dipegangi oleh kalangan Islam liberal. Mereka menampilkan dalil-dalil yang menguatkan pendapat mereka tentang perbedaan antara kafir musyrik dan kafir Ahli Kitab. Abu al A'la al Maududi mengatakan: "Buka dan bacalah al-Qur'an dari awal, mulai dari surat al-Fatihah, sampai akhirnya, surat an-Nas, kita akan temukan tiga kategori kepercayaan dengan istilah-istilah yang antara satu dan lainnya, arti dan maknanya berbeda, yakni term musyrik, istilah Ahli Kitab, dan istilah abl al iman.

Menurut Abdul Moqsith Ghazali, dalam surat al-Mumtahanah ayat 10 sudah jelas tentang pernikahan laki-laki, pernikahan umat Islam dengan orang kafir itu ditutup sama sekali. Wala tumsiku bi' Islam al-Kawafir. Sementara al-Baqarah ayat 221, Wala tankihu al-musyrikat ..... wala tunkihu al-musyrikin. Umat Islam tidak diperbolehkan menikah dengan laki-laki dan perempuan musyrik. Sementara ada ayat lain, QS al-Ma'idah ayat 5 yang memperbolehkan menikah dengan perempuan

${ }^{33}$ Nurcholish Madjid et.al. Fiqh Lintas Agama: Membangun Masyarakat Inklusif Pluralis (Jakarta: Paramadina, 2004), hlm. 156-157.
Imam Hurmain, Pernikahan Lintas Agama dalam Perspektif...

ahlul kitab. Wal al-muhshanatu minal ladzina utul kitaba min qoblikum. Perlu kita maklumi bahwa al-Baqarah itu adalah surat yang pertama kali turun ketika Nabi berada di Madinah. Kemudian ayat berikutnya Al-Mumtahanah ayat 10, baru kemudian terakhir turun al-Ma'idah ayat 5. Sebagian ulama ${ }^{34}$ berpandangan bahwa ayat yang terakhir turun yang memperbolehkan menikah dengan ahlul kitab itu telah mentahsish, menspesifikasi dua ayat sebelumnya. Jadi boleh menikah dengan ahlul kitab, yang pada zaman dulu adalah Yahudi dan Nasrani. Ahli kitab telah dikecualikan dari keumuman ayat kafir dan musyrik. Dalam ushul fiqh Syafi'i, ini disebut tahshish, sedangkan dalam ushul fiqh Maliki disebut sebagai nasakh juz'iy.

Ada pendapat lain yang menyatakan bahwa karena ayat yang terakhir turun itu adalah ayat yang memperbolehkan nikah dengan ahlul kitab, maka ayat ini telah mengamandemen pelarangan menikah dengan orang kafir dan orang musyrik sebelumnya. Oleh karena yang terakhir ini mempunyai otoritas untuk menganulir ketentuan yang ada sebelumnya. Dan tidak bisa berlaku hukum sebaliknya dua ayat yang sebelumnya akan menganulir hukum yang ada setelahnya. Itu yang dimaksud dalam kaidah ushul fiqh la yajuzu taqadumum nasikh alal mansukh. Yang dinasakh itu selalu harus datang yang paling akhir. Jadi boleh. Pendapat ini dapat dikemukakan penjelasannya dalam tafsir alThabary.

\section{c. Pluralisme}

Secara historis, istilah pluralisme diidentifikasikan dengan sebuah aliran filsafat, yang menentang konsep negara absolut dan berkedaulatan. Sementara pluralisme klasik merupakan reaksi terhadap doktrin hukum tentang kedaulatan Negara; pluralisme kontemporer, yang muncul tahun 1950-an, dikembangkan tidak untuk menentang

34 Di antara ulama yang berpendapat ini antara lain Qatadah, Thalhah, Ikrimah, Sa'ad bin Jubair Makhul, Hasan Dhahak. Lihat Ibnu Katsir.. Tafsir AlQuran Al-Azhim (Beirut: Dar al-Ma'rifah, 2004), hlm. 200; Al-Thabari Tafsir alThabariy. (Beirut: Dar al-Kutub al-'Tlmiyah, 1999), hlm. 386-392; Al Zamakhsari Tafsir al-Kasysyaf. (Beirut: Dar al-Kitub al-'Ilmiyah, 2003), hlm. ; Al-Baidhawi Tafsir al-Baidhawiy. (Beirut: Dar al-Kutub al-'Tlmiyah, 2003), hlm. 
A1-Fikra: Jurnal Ilmiah Keislaman, Vol. 7, No. 1, Januari-Juni 2008

kedaulatan negara, tetapi untuk menentang teori-teori tentang elit (Mouw, 1993).

Namun dalam kaitannya dengan landasan pembolehan pernikahan lintas agama ini, yang dimaksud pluralisme adalah pluralisme agama (religion pluralism). Hal merujuk pada rumusan Hick dalam Encuclopedia of Religion, yang diartikan sebagai "teori yang merujuk pada hubungan antara beberapa agama atau tradisi dengan klaim-klaimnya yang saling berlawanan". Menurut Hick, agama-agama besar di dunia sebenarnya merupakan satu konsepsi yang berbedabeda sebagai respon terhadap "the ultimate". Agama-agama yang ada adalah hanya merupakan "different manifestation, of the same reality".

Menurut Nurcholish Madjid semua agama yang benar pada hakikatnya adalah "al-Islam”, yakni semuanya mengajar sikap pasrah kepada Sang Maha Pencipta, Tuhan yang Maha Esa. Dalam kitab suci berulang kali ditegaskan bahwa agama para nabi sebelum nabi Muhammad saw. adalah semuanya al-Islam karena semuanya adalah ajaran tentang sikap pasrah kepada Tuhan. Perbedaan agama hanya pada level eksoterik (lahir), sedangkan awal level esoteriknya (batin) relatif sama. ${ }^{35}$

Alwi Shihab memahami pluralisme dengan kemajemukan dan tidak sama menyamakan semua agama. Menurutnya secara garis besar pengertian konsep pluralisme agama dapat disimpulkan sebagai berikut: Pertama, pluralisme tidak semata menunjukkan pada kenyataan tentang adanya kemajemukan. Namun yang dimaksud adalah keterlibatan aktif terhadap kenyataan kemajemukan tesebut. Kedua, pluralisme harus dibedakan dengan kosmopoktanisme. Kosmopolitanisme menunjuk pada suatu realita di mana aneka ragam agama, ras, bangsa yang berdampingan di satu lokasi. Ketiga, konsep pluralisme tidak sama dengan relativisme. Seorang relativisme akan berasumsi bahwa hal-hal yang menyangkut "kebenaran" atau "nilai" ditemukan oleh pandangan hidup serta kerangka berpikir seseorang atau masyarakatnya dan Keempat, pluralisme bukanlah sinkritisme, yakni menciptakan suatu agama baru, dengan memadukan unsur

35 Nurcholish Madjid, Islam Doktrin dan Peradaban (Jakarta: Paramadina, 2000), hlm. 452-441.
Imam Hurmain, Pernikahan Lintas Agama dalam Perspektif...

tertentu atau sebagian komponen ajaran dari beberapa agama untuk dijadikan bagian integral dari agama baru tersebut. ${ }^{36}$

Pada prinsipnya konsep pluralisme yang diusung oleh JIL sama dengan konsep Hick dan pandangan Cak Nur di atas. Ulil Abshar Abdalla menyatakan "Kebenaran Tuhan lebih besar dari Islam itu sendiri sebagai agama yang dipeluk oleh entitas sosial yang bernama umat Islam. Islam hanyalah sebuah "proses" yang tak pernah selesai. Oleh sebab itu ayat Inna al-ddina inda Allahi al-Islam (QS 3:19) lebih tepat diartikan sebagai "Sesungguhnya jalan religiusitas yang benar adalah proses yang tidak pernah selesai menuju ketundukan (kepada Yang Maha Esa)."

Lebih jauh Ulil mengatakan, semua agama adalah tepat berada pada jalan seperti itu, jalan panjang menuju Yang Maha Benar. Semua agama, dengan demikian, adalah benar, dengan variasi, tingkat dan kadar kedalaman yang berbeda-beda dalam menghayati jalan religiusitas itu, semua agama ada dalam satu keluarga besar yang sama: yaitu keluarga pencipta jalan menuju kebenaran yang tak pernah ada ujungnya.

Budhy Munawar Rahman, salah satu kontributor JIL memberikan legitimasi kepada "kebenaran semua agama" bahwa pemeluk semua agama layak disebut sebagai "orang yang beriman" dengan makna "orang yang percaya dan menaruh, kepercayaan kepada Tuhan" karena itu sesuai dengan QS 49: 10-12 mereka adalah bersaudara dan seiman. Oleh karena itu yang diperlukan sekarang ini dalam penghayatan masalah pluralisme antara agama, yakni pandangan bahwa siapapun yang beriman tanpa harus melihat agamanya adalah sama di hadapan Allah. Karena Tuhan kita semua adalah Tuhan yang satu." 37

Penjelasan Rahaman tentang pluralisme di atas menurut Adian Husaini sebenarnya campur aduk antara konsep keyakinan pada level teologis dan aplikasi sosiologisnya di lapangan. Seorang yang

${ }^{36}$ Alwi Shihab, Islam Inklusif: Menuju Sikap Terbuka dalam Beragama. (Bandung: Mizan, 2001), hlm. 41

37 Budhy Munawar-Rahman dalam Adian Husaini et.al. Membedah Islam Liberal, (Bandung: PT. Syamil Cipta Media, 2003), hlm. 65 
Al-Fikra: Jurnal Ilmiah Keislaman, Vol. 7, No. 1, Januari-Juni 2008

menyakini tanpa keraguan, konsep aqidahnya, tentu akan memiliki keyakinan, konsepsi aqidah lain yang bertentangan dengan konsepsi aqidahnya, sebagai hal yang salah. Itu berlaku secara otomatis, terutama untuk dua hal yang bersifat paradoks. Pada level teologis, seyogyanya masing-masing agama dibiarkan berbeda, sesuai dengan keyakinannya masing-masing.

Selain itu konsep pluralisme versi Rahman yang melarang seorang pemeluk agamanya menyakini kebenaran konsep teologisnya secara ekslusif. Selain naif juga merusak keimanan. Iman Islam, misalnya, mensyaratkan adanya "yakfur bi at-thaghut". Iman mengharuskan keyakinan, tidak ada keraguan. Soal ketakutan Paramidana terhadap panatisme Islam, hanyalah mengulang lagu lama sejarah kolonial Belanda. ${ }^{38}$

Konsep pluralisme di atas merupakan salah satu agenda penting Jaringan Islam liberal sebagaimana diungkapkan promotor JIL Assyaukanie yang menyatakan tentang pentingnya teologi pluralisme dan tidak bisa ditawar-tawar. Pengalaman historis bisa dilihat pada awal-awal masyarakat Madinah yang dipimpin Nabi, sering dijadikan model percontohan adanya toleransi kehidupan antar-agama dalam Islam. Dengan model ini, Islam dianggap sebagai agama yang menghormati keberadaan agama-agama lain, inklusif, dan toleran. Dengan melihat konsep pluralisme ini, maka tidak ada halangan untuk melakukan pernikahan antara pemeluk agama yang berbeda baik lakilaki maupun perempuan. Karena pada hakikatnya semua agama adalah sama menuju Tuhan, hanya saja ada perbedaan dalam ekspresi beragama masing-masing umat.

Namun pemahaman semacam ini merupakan pemahaman yang terlalu berani, karena mengaburkan kebenaran agama Islam dan menganggap kebenaran semua agama. Dan hal ini sangat berbahaya apabila sampai diketahui oleh orang awam namun ia tidak dapat memahaminya. Selain itu pemahaman seperti ini rentan akan kekufuran. Penulis lebih condong dengan konsep pluralisme Alwi

38 Adian Husaini, Sunday, 15 June 2003. Pluralisme, Kafir, dan Toleransi (Catatan untuk. Budby Manawar Rachman) dalam http://www.islamlib.com11/05/05)
Imam Hurmain, Pernikahan Lintas Agama dalam Perspektif...

Shihab yang memandang pluralisme sebagai suatu kemajemukan dan bukan menyamakan semua agama.

Menanggapi isu pluralisme agama, Al-Lajna al-Da'imah li al-Bubus al-'Imiyyah wa al-Ifta' juga pernah mengeluarkan penetapan (No. 19402 Tanggal 25/1/1418 H.) yang di antara isinya:

"Pertama, di antara dasar iktikad Islam yang termasuk al-ma'lumah minaddin bil dlarurah dan yang telah menjadi kesepakatan orang-orang Islam, adalah bahwa tidak ada agama di muka bumi ini yang benar kecuali Islam.... Kelima, bahwa wajib untuk meyakini kekafiran orang yang tidak masuk Islam dan menyebut mereka sebagai kafir...barang siapa yang tidak mengkafirkan orang Yahudi dan Nasrani maka dia kafir, sesuai kaidah: "man lam yukaffir al-kafira fahwa kafirun".... Kesembilan, tidak boleh bagi orang Islam yang beriman kepada Allah sebagai Tuhan, Islam sebagai agama, dan mengakui Muhammad sebagai nabi, untuk berpartisipasi dengan segala bentuknya dalam gerakan tersebut (wabdat al-adyan, atau mendekatkan antara agamaagama tersebut dalam sumber yang sama)". 39

Sementara Majelis Ulama Indonesia (MUI) menanggapi polemik pluralisme $^{40}$ ini dengan mengeluarkan fatwa yang mengharamkan paham pluralisme. MUI menyatakan bahwa "Pluralisme, sekularisme dan liberalisme agama sebagaimana dimaksud dalam bagian pertama adalah faham yang bertentangan dengan ajaran agama Islam. Umat Islam haram mengikuti paham pluralisme, sekularisme, dan liberalisme agama.

\section{d. Universalisme demi Kemaslahatan}

${ }^{39}$ Khalid 'Abd al-Rahman, Al-Fatawa al-Syar'iyyah fi al-Masa'il al-'Ashriyyah min Fatawa 'Ulama al-Balad al-Haram, (Riyadl: Mu'assasah al-Juraiysiy, 1999), hlm. 116123.

40 Pluralisme dalam rumusan fatwa MUI adalah pluralisme adalah faham yang mengajarkan bahwa semua agama adalah sama dan karenanya kebenaran setiap agama adalah relatif. Karena itu setiap pemeluk agama tidak boleh mengklaim bahwa hanya agamanya saja yang benar sementara agama yang lain salah. Pluralisme juga mengajarkan bahwa semua pemeluk agama akan hidup berdampingan di dalam surga. 
A1-Fikra: Jurnal Ilmiah Keislaman, Vol. 7, No. 1, Januari-Juni 2008

Islam merupakan agama yang sangat menganjurkan nilai-nilai universal seperti keadilan, persatuan, persaudaraan, perdamaian dan nilai-nilai universal lainnya. Menurut kalangan Islam liberal ayat-ayat universal dan partikular, dan nilai-nilai universalitas Islam terkandung di dalam ayat-ayat al-Qur'an yang bersifat universal. Nilai-nilai ini harus ditegakkan oleh setiap Muslim, sehingga apabila ada perbedaan antara ayat universal dengan ayat partikular maka yang harus dimenangkan adalah ayat-ayat yang universal. Hal ini untuk menegakkan tujuan Islam yang sebenarnya, yaitu untuk menjaga kemaslahatan manusia.

Kemaslahatan (al-mashlahah) ${ }^{41}$ sebagai maqashid al-syariah merupakan dasar pembentukan hukum Islam harus diprioritaskan sebagai sarana untuk menegakkan nilai-nilai universal Islam. Bahkan kalangan JIL membolehkan amandemen teks-teks agama nash bila bertentangan dengan kemaslahatan masyarakat. Mereka mengeluarkan beberapa kaidah yang biasa disebut dengan ushul fiqih liberal yang diciptakan oleh Abdul Moqisth Ghazali:

a) Al-Tbrah bi al-maqashid la bi al-alfazh (yang menjadi patokan hukum adalah maksud/tujuan syariat, bukan ungkapannya [dalam teks]);

b) Jawaz naskh nushush bi al-mashlahah (Boleh menghapus nash dengan maslahat);

c) Tanqih nushush bi 'aql al-mujtama' (Boleh mengoreksi teks dengan akal [pendapat] publik) ${ }^{42}$

4 Secara etimologi maslahah sejenis dengan kata manfaah, baik ukuran dan artinya. Kata mashlahah merupakan masdar yang mengandung arti kata al-sholah seperti kata manfa'ah yang mengandung arti al-naf. Kata mashlahab merupakan bentuk mufrad dari kata mashalih, sebagaimana diterangkan pengarang kitab lisan al'Arab yaitu setiap sesuatu yang mengandung manfaat baik dengan cara mendatangkan sesuatu yang berguna maupun dengan menolak sesuatu yang membahayakan. Sedangkan secara terminology mashlahah yaitu manfaat yang menjadi tujuan Syari' untuk hamba-Nya. Manfaat dalam arti suatu yang nikmat atau yang mendatangkan kenikmatan. Lihat. Ramadhan al-Buthy, Dhawabith al-Mashlahab fi al-Syari'ah al-Islamiyah, (Beirut: Muassasah al-Risalah, 1986), hlm. 23; 'Izzudin 'Abdul 'Aziz, Qowaid al-Abkam fi Mashalih al-Anam, (Beirut: Dar al-Kutub al'Ilmiyah, t.th), hlm. 7-8.
Imam Hurmain, Pernikahan Lintas Agama dalam Perspektif...

Berpijak pada pandangan universalisme Islam di atas maka tidak ada alasan yang melarang pernikahan antar umat beragama, bila di dalamnya akan mendatangkan mashlahat. Nilai maslahat ini dapat dilihat dari perspektif akal manusia pada umumnya. Jika menurut pandangan akal manusia secara mayoritas itu baik, karena di dalamnya mengandung maslahat, maka hal itu merupakan maslahat.

Padahal kalau hanya berdasarkan nilai kemaslahatan, di dalam maslahat ada standar yang diperhitungkan syara' bagi maslahat dan mafsadat yang menjadi dasar tasyri' umum, sehingga dapat mencakup individu dan masyarakat secara bersamaan dan menimbang antara kebutuhan yang segera dan yang tidak segera. Karena itu, tidak dianggap sebagai maslahat kecuali sesuatu yang dipandang, oleh syara' sebagai suatu maslahat. Hal ini untuk mencegah dari kekacauan standar pribadi, sehingga yang menjadi standar adalah syara'. ${ }^{33}$ Kriteria-kriteria untuk menentukan mashlahat menurut syara' adalah: Pertama, memprioritaskan tujuan-tujuan syara'. Kedua, tidak bertentangan dengan Al-Quran. Ketiga, tidak bertentangan dengan alSunnah. Keempat, tidak bertentangan dengan prisip qiyas dan Kelima, memperhatikan kepentingan umum yang lebih besar. ${ }^{44}$

\section{Kesimpulan}

Jaringan Islam Liberal (JIL) merupakan kelompok yang tergolong baru di Indonesia, namun demikian ternyata JIL mampu menciptakan pengaruh yang tidak bisa dianggap sepele di kalangan masyarakat. Produk pemikiran hukum yang mereka kemukakan tampaknya mulai ada yang mengikuti, atau setidak-tidaknya, membuat keraguan (tasykik) secara meluas atas pemahaman Islam yang telah mapan dan melembaga.

Melihat realitas masyarakat Indonesia yang sangat kompleks dan plural, mereka membolehkan pernikahan lintas agama. Menurut mereka al-Qur'an juga tidak pernah secara tegas melarang hal itu,

43 Musthafa Ahmad Al-Zarqa, Al-Istishlah wa al-Mashalih al-Mursalah, (Damaskus: Dar al-Qalam, 1988), hlm. 39-40.

${ }^{44}$ Ramadhan al-Buthy, Dhawabit, hlm. 129. 
A1-Fikra: Jurnal Ilmiah Keislaman, Vol. 7, No. 1, Januari-Juni 2008

karena al-Qur'an menganut pandangan universal tentang martabat manusia yang sederajat, tanpa melihat perbedaan agama. Segala produk hukum Islam klasik yang membedakan kedudukan orang Islam dan non-Islam harus diamandemen berdasarkan prinsip kesederajatan universal dalam tataran kemanusiaan.

Berbagai ragam pemikiran yang ditelorkan oleh Jaringan Islam Liberal (JIL), khususnya pada permasalahan nikah beda agama sebenarnya lebih dapat dikatakan sebagai wacana saja. Berkaitan dengan hal ini, respon paling positif yang seharusnya dimunculkan oleh umat Islam adalah membuka ruang diskusi yang selebar-lebarnya demi terciptanya perkembangan pemikiran di kalangan umat Islam yang semakin dinamis. Sebagai seorang Muslim, upaya strategis yang perlu dilakukan untuk menjaga stabilitas kehidupan beragama adalah tetap menjalani apa yang digariskan hukum Islam dan hukum positif secara normatif dalam hal pernikahan sebagaimana dipahami umat Islam kebanyakan saat ini, mengingat pernikahan beda agama yang dilegalkan oleh JIL mau tidak mau akan membawa suatu dampak psikologis-sosiologis yang negatif ketika dibenturkan dengan realitas masyarakat Muslim kebanyakan saat ini.

\section{Bibliografi}

Abdalla, Muhammad dan Rasyid Ridha, Tafsir al-Mannar, (t.tp: Dar alFikr, t.th).

Abdalla, Ulil Abshar et al. Islam Liberal dan Islam Fundamental: Sebuah Pertarungan Wacana, (Yogyakarta: Alsaq Press, 2003).

Abdalla, Ulil Abshar. Inter-Tekstualitas Qur'an dan Wabyu yang Hidup Pembaca "baru" atas Qur'an: go beyond text. www.islamlib.com. 30/09/2002

Abduh, Muhammad dan Rasyid Ridha, Tafsir Al-Manar, (Beirut: Dar al-Ma'arif, t.th).

Abegabriel, Agus Maftuh, Negara Tuhan, (Yogyakarta: SR-INS Publishing, 2004).
Imam Hurmain, Pernikahan Lintas Agama dalam Perspektif..

Ahmad, Kamaruzzaman Bustamam, Wajah Baru Islam di Indonesia, (Yogyakarta: UII Press, 2004).

Alfitri, Studi Quran Kontemporer: Telaah atas Hermeunetika Quran Nashr Amid Abu Zaid: dari Mïlah Jurnal Studi Agama, Vol. II No. 2., 2002

Assyaukainie, Luthfi, Empat Agenda Islam Yang Membebaskan, www.islamlib.com. 2002.

Wajah Liberal Islam di Indonesia, (Jakarta: Teater Utan Kayu, 2002)

Wajah Liberal Islam di Indonesia, (suntingan). (Jakarta: Jaringan Islam Liberal, 2002).

Baidhawiy, Tafsir al-Baidhawiy, (Beirut: Dar al-Kutub al-'Tlmiyah, 2003).

Barton, Greg, Gagasan Islam Liberal di Indonesia, (Jakarta: Pustaka Antara, 1999).

Binder, Leonard, Islam Liberal: Kritik Terbadap Ideologi-ideologi Pembangunan, (Yogyakarta: Pustaka Pelajar, 2001).

Buthy, Ramadhan, Dhawabith al-Mashlabah fi al-Syariah al-Islamiyah, (Beirut: Muassasah al-Risalah, 1986).

Esposito, John L. dan John O. Voll., Islam and Democracy, (terj), (Bandung: Mizan, 1999).

Grose, Greg B. dan Banjamin J. Jubbard, Tiga Agama Satu Tuban, (Bandung: Mizan, 1999).

Haryono, Yudhie R., Post Islam Liberal, (Bekasi: Airlangga Pribadi, 2002).

Humaidy, Syaikh Humaidy bin Abdul Aziz, Kawin Campur dalam Syariat Islam, (Jakarta: Pustaka Alkautsar, 1992).

Husaini, Adian dan Nuim Hidayat, Islam Liberal: Sejarah, Konsepsi, Penyimpangan dan Jawabannya, (Jakarta: Gema Insani Press, 2003). 
Al-Fikra: Jurnal Ilmiah Keislaman, Vol. 7, No. 1, Januari-Juni 2008 et. al., Membedah Islam Liberal, (Bandung: PT Syamil Cipta Media, 2003).

, Pernikahan Lintas Agama, Republika, Jumat 15 April 2005.

Ichsan, Ahmad, Hukum Perkawinan Bagi yang Beragama Islam, Jakarta: PT Pradnya Paramita, 1987).

Ilyas, Hamim, Dan Ahli Kitab Pun Masuk Surga: Pandangan Muslim Modernis terhadap Keselamatan Non-Muslim, Yogyakarta: Safitria Insani Press, 2005).

Izzuddin 'Abdul 'Aziz, Qowaid al-Ahkam fi Mashalih al-Anam, (Beirut: Dar al-Kutub al-'Ilmiyah, t.th).

Jabry, Abdul Muta'al Muhammad, Pernikahan Campuran Menurut Pandangan Islam, (Surabaya: Risalah Gusti, 1992).

Jaiz, Hartono Ahmad, Menangkal Bahaya JIL FLA, Jakarta: Pustaka Al-Kautsar, t.th).

Katsir, Ibnu, Tafsir Al-Quran Al-Az̧bim, (Beirut: Dar al-Ma'rifah, 2004).

Kurziman, Charles, Liberal Islam Source Book, (New York: Oxford University Press, 1998).

Lewis, Bernard. et.al., Islam Liberalisme Demokrasi: Membangun Sinerji Warisan Sejarah, Doktrin dan Konteks Global, Jakarta: Paramadina, 2002).

Liddle, William, Islam, Politik dan Modernisasi, (terjemahan), (Jakarta: Pustaka Sinar Harapan, 1887).

Madjid, Nurcholish, Islam Doktrin dan Peradaban, (Jakarta: Paramadina, 2000). , et.al., Fiqih Lintas Agama,(Jakarta: Paramadina. 2004).

Mahmada, Nong Daral dan Burhanuddin, Jaringan Islam Liberal (IIL) : Pewaris Pemikiran Pembaruan Islam di Indonesia, dalam buku Imam Tolkhah dan Neng Dara Affiah (ed.) Gerakan Keislaman Pasca Orde Baru Upaya Merambah Dimensi Baru
Imam Hurmain, Pernikahan Lintas Agama dalam Perspektif...

Islam, Jakarta: Badan Litbang Agama PAN Diklat Keagamaan Dep. Agama RI, 2005).

Malik, Dedy Jamaluddin dan Idi Subandy Ibrahim, Zaman Baru Islam Indonesia, (Bandung: Zaman Wacana Mulia, 1998).

Mcinner, William, Agama di Abad Duapulub Satu dari, Ulumul Quran Jurnal Ilmu dan Kebudayaan, Vol II. 1990

Mu'tamar, Khalif, Liberalisasi Islam dan Agenda Global Barat, Copyright@2003 INSISTNET.COM.04/07/03.2003

Nasih, Mohammad, Memahami Konsep Islam Liberal, www.islamlib.com. 30/09/2002. 2002.

Nurcholish, Ahmad, Memoar Cintaku, (Yogyakarta: LkiS, 2004)

Qodir, Zuli, Islam Liberal: Paradigma Baru Wacana dan Aksi Islam Indonesia, (Yogyakarta: Pustaka Pelajar, 2003).

Rahman, Budhy Munawar, Islam Pluralis: Wacana Kesetaraan Kaum Beriman, (Jakarta: Paramadina, 2001).

Rusli dan R. Tama, Perkawinan Antar-Agama dan Masalabnya, (Bandung: Pionir Jaya, 1986)

Rusyd, Ibnu, Bidayah al-Mujtahid, (Beirut: Dar al-Jalil, 1989).

Sabiq, Sayyid, Fiqh al-Sunnah, (Beirut: Dar al-Fikr, 1983)

Sagiv, David, Islam Otentitas Liberalisme, (Yogyakarta: LkiS, 1997)

Sanuwi, Abu Hamzah, Akar Fitnah dalam Sejarah Umat Islam Hingga Labirnya JIL http/www://forsitek.brawijaya.ac.id/03/05/05. 2002.

Shabuni, Muhammad Ali. Rawai' al-Bayan Tafsir Ayat al-Abkam min alQuran, (Beirut: Dar al-Kutub al-Islamiyah, 2001).

Shihab, ALwi, Islam Inklusif: Menuju Sikap Terbuka Dalam Beragama, (Bandung: Mizan, 2001).

Shihab, Muhammad Quraish, Tafsir al-Mishbah: Pesan, Kesan, dan Keserasian Al-Quran, (Jakarta: Lentera Hati, 2002). 
Al-Fikra: Jurnal Ilmiah Keislaman, Vol. 7, No. 1, Januari-Juni 2008 Wawasan Al-Quran, (Bandung: Mizan, 2000).

Syahrur, Muhammad, Hermeunetika Al-Quran, (Yogyakarta: Elsaq, 2004).

Syarbiny, Syaikh Muhammad, Syarh Mughni al-Mukhtaj, (Riyadh: Ihya Turats al-'Araby, t.th)

Syaukani, Muhammad Ali, Fath al-Qodir, (Beirut: Dar al-Kutub al-'Ilmiyah, 2003).

Thabariy, Tafsir al-Thabariy, (Beirut: Dar al-Kutub Al-'Ilmiyah, t.th).

Ulfah, Anshor Maria Martin Lukito Sinaga, (ed) Tafsir Ulang Perkawinan Lintas Agama: Perspektif Perempuan dan Pluralisme, (Jakarta: KAPAL Perempuan, 2004).

Undang-Undang Perkawinan No. 1 Tahun 1974. (Surabaya: Arkola, 1998).

Wahid, Ahmad Bunyan, Jaringan Islam Liberal: Towards A Liberal Islamic Thoght In Indonesia, Jurnal Studi Islam Profetikal, Vol. 6, No. 1, Diterbitkan Program Magister Studi Islam Universitas Muhammadiyah Surakarta, 2004).

Wahid, Shalahuddin, Perkawinan, Agama dan Negara, Republika, Jumat, 1 April. 2005.

Watt, W. Montgomery, Kerajaan Islam: Kajian Kritis dari Tokoh Orientalis, (Yogyakarta: Tiara Wacana Yogya, 1990).

Wijaya, Aksin, Menggugat Otentitas Wabyu Tuhan, Yogyakarta: Safiria Insani Press, 2004).

Zamakhsyariy, Tafsir al-Kasysyaf, (Beirut: Dar al-Kutub al-'Ilmiyah, 2003).

Zarqa, Mushtafa Ahmad, Al-Istishlah wa al-Mashalih al-Mursalab: Membongkar Kebusukan Sekularisme, dari Majalah Hidayatullah, Edisi Desember, 2003.

Zuhailiy, Wahbah, Tafsir Al-Wasith, (Beirut: Dat al-Fikr al-Ma'ashir, 2000).
Imam Hurmain, Pernikahan Lintas Agama dalam Perspektif... , Al-Figh al-Islami wa Adilatubu, (Damaskus: Dar al-Fikr, 2004). 